ment, including the Central Training Council, the National Advisory Council on Education for Commerce and Industry and the Redditch New Town Development Corporation. The first Vice-Chancellor will be Sir Peter Venables, at present the Principal of the College. Sir Peter has been Principal since 1956. The draft for the Charter of the new University has been submitted to the University Grants Committee for comment ; it is anticipated that the petition for the Royal Charter incorporating the new University will shortly be submitted to the Privy Council, and it is hoped that the Charter may be granted before the beginning of the next academic session in October 1965.

\section{Economics and Statistics Committee formed by the Scientific Instrument Manufacturers' Association}

'THe Scientific Instrument Manufacturers' Association has set up an Economics and Statistics Committee to meet the needs of the Association and its members. This Committee will co-operate elosely with other bodies doing similar work. The importance of statistical and economic information has become increasingly recognized over the past few years. Government departments and the National Economic Development Council require fuller information in their task of formulating plans, and the demand from companies for data to assist in market research and to assess their own position has greatly increased. Basically two types of information are sought: accurate and detailed data extending back over a reasonable period of time on sales, exports, imports; and secondly, an assessment of trends within the industry and forecasts of future trends. The Economics and Statistics Committee will act as an advisory body to the Council of the Association for the provision of economic and statistical information. It will determine the information likely to be of value to the industry, advise on its collection, analysis and dissemination, and consider methods of improving it. Another aspect of the work of whe Committee will be the formulation of terms and definitions for use in the statistics work of the Association. The Committee is composed of members representing each of the sections of the instrument industry and is under the chairmanship of Mr. H. C. Pritchard (Cambridge Instrument Co., Ltd.).

\section{The Confederation of British Industry}

THE Integration Committee appointed to supervise the establishment of a national industrial organization by the amalgamation of the National Association of British Manufacturers, the Federation of British Industries and the British Employers' Confederation has announced that a revised Charter (on the lines of the outline plan already circulated to members) is in the course of preparation, and it is expected that meetings of members of the three bodies concerned will be held on March 24 at which the integration agreement will be presented for approval.

On this basis the Integration Committee proposes that, to take effect as soon after the meetings as practicable (the anticipated effective date being early in August): (a) the name of the new organization shall be the Confederation of British Industry (C.B.I.); (b) the first president of the C.B.I. shall be Mr. M. Laing; (c) the first vice-presidents of the C.B.I. shall be Sir Poter Runge and Mr. L. Jenkins; $(d)$ the office of deputy president shall be created, but no immediate appointment to this office is proposed; (e) the first director-general of the C.B.I. shall be Mr. J. Davies, at present vice-chairman and a managing director of Shell Mex and B.P., Ltd., who will take up his post on the effective date; $(f)$ Mr. P. F. D. Tennant, at present deputy director-general of tho Federation of British Industries, shall be relieved of general duties during the formative period of the C.B.I. in order to give special assistance to the director-general; (g) appointments to the posts of deputy director-general of the C.B.I. shall be made by the director-general in consultation with the president in due course; $(h) \mathrm{Mr}$. H. J. Gray will continue as director of the National Association of British Manufacturers until the effective date, when he shall be appointed director of regions in the C.B.I.; (i) Mr. D. Taylor, at present deputy director of the British Employers' Confederation, shall be appointed director of labour and social affairs in the C.B.I.; $(j)$ Sir Norman Kipping will continue as director-general of the Federation of British Industries until the effective date and thereafter will be available to the C.B.I. on a parttime basis for consultation until his normal retirement date on May 11, 1966; (k) Sir George Pollock will resign his post as director of the British Employers' Confederation with effect from June 30. Mr. D. Taylor, the present deputy director, will assume the position of acting director of the body from July 1 until the effective date. Sir George will be available to the C.B.I. on a part-time basis for consultation and will also represent the C.B.I. at the International Labour Organization.

If the proposals for a revised Charter are accepted, a formal petition will be submitted to Her Majesty in Council, requesting the grant of a Supplemental Charter.

\section{Laboratory Animals}

A DIRECTORY of sources of laboratory animals, and of suppliers of equipment and materials connected with their maintenance, is prepared by the Institute of Laboratory Animal Resources. The fifth edition is now available (Laboratory Animals. II, Animals for Research. Publication 1199. Pp. 89. Washington, D.C.: National Academy of Sciences-National Research Council, 1964. 2 dollars). The directory comprises five sections: Section I lists the common mammalian and avian laboratory species, giving the strain designation and the breeding system; Section II lists the species of animals "obtained from Nature" and available through commercial suppliers; and Section III lists feedstuffs, cages and other equipment. Each item in these sections is referred to by a code number, and the fourth section of the booklet provides a guide to the manufacturer and suppliers of the animals and equipment coded in the first three sections. In the final section the animals are indexed by taxonomic and vernacular names.

\section{Soils and Land-use in Buckinghamshire}

A RECENTLY published memoir of the Soil Survey of Great Britain by B. W. Avery describes the soils and features of the region mapped on Sheet 238 (The Soils and Land Use of the District around Aylesbury and Hemel Hempstead. Pp. vii $+216+11$ plates. London: H.M.S.O., 1964. 35s. net). The total area amounts to 216 square miles, of which about two-thirds comprise part of the Chiltern plateau of Chalk upland, which falls in a southeasterly direction down to $400 \mathrm{ft}$. from an indented scarp north-east-south-west and rising to $800 \mathrm{ft}$. The 'Jcknield Belt' lies between the escarpment and the Vale of Aylesbury to the north-west, which is mainly on Gault and Kimmeridge clays. This momoir is the first to give a detailed account of soils overlying Cretaceous rocks and associated superficial deposits. The first chapter concerns the geology, physiography and climate of the area and discusses local fluctuations from the average daily maximum and minimum temperatures of $55^{\circ}$ and $42^{\circ} \mathrm{F}$ and the reasons for an average summer soil moisture deficit of about 4 in. More than half the volume is devoted to a discussion of soil formation processes and survey methods-there is a useful appendix defining the terms used in profile description-and to the classification of calcareous, brown earth, podzol and gley groups of soils, with details of representatives of various series. There is a chapter on land-use capability and requirements for which much valuable information has been derived from 